\title{
PENGARUH AGRESIVITAS PAJAK TERHADAP BEBAN HUTANG PADA PERUSAHAAN MANUFAKTUR TAHUN 2012-2014
}

\author{
Ernie Riswandari \\ Universitas Bunda Mulia \\ eriswandari@bundamulia.ac.id
}

\begin{abstract}
This study aims to empirically examine the factors that affect the level of financial statements disclosure, using financial leverage, size, auditor type, profitability, age, and risk as independent variable.

This study was conducted using multiple regression analysis and data processing with the E-views 6.0 program. The data in this research is secondary data obtained from the audited financial statements for 2010-2014 and the annual report for 2011-2013. The population in this study amounted to 141 companies, which obtained a sample of 69 companies and 207 units of observation (69 companies multiplied by 3 years).

The results from this study indicate that there are two independent variables to be significant with level of disclosure of firm report, financial leverage to be negative significant for determining the level disclosure and firm size has a positive significant with the level disclosure. While 4 other variables, auditor type, the profitability, firm age and firm risk insignificant with the level of disclosure.
\end{abstract}

Key words : financial statement disclosure, leverage, size, auditor type, profitability, age, risk

\section{Pendahuluan}

Keseimbangan financial tercermin

dari struktur modal. Keputusan

struktur modal dalam perusahaan

merupakan hal penting. Pentingnya

struktur modal ini karena adanya

pilihan kebutuhan antara me-

maksimalkan return (memini-malkan

biaya modal) dengan kemampuan

perusahaan dalam menghadapi

lingkungan bisnis yang kompetitif.
Stuktur modal perusahaan adalah kombinasi dari saham-saham yang berbeda (saham biasa dan saham preferen) atau bauran seluruh sumber pendanaan jangka panjang (ekuitas dan hutang) yang digunakan. Pada umumnya, suatu perusahaan memiliki berbagai alternatif dalam mengoptimalkan struktur modal. Namun seringkali para manager menghadapi kesulitan dalam 
menentukan bagaimana struktur modal yang optimal, darimana modal diperoleh, dan bagaimana mengelolah modal agar memberikan keuntungan bagi perusahaan. Untuk memilih menggunakan modal sendiri atau modal pinjaman (hutang) haruslah menggunakan beberapa perhitungan salah satunya dengan rasio struktur modal. Keputusan berutang dianggap sebagai salah satu solusi untuk mempercepat aktivitas produksi dan juga mempertahankan posisi perusahaan.

Dengan berdasarkan pada latar belakang tersebut maka dapat disusun rumusan permasalahan sebagai berikut :

Bagaimana pengaruh agresivitas pajak terhadap beban hutang pada perusahaan manufaktur 2012-2014?

\section{Tinjauan Pustaka}

\subsection{Teori Struktur Modal Tradisional}

Pendekatan tradisional pada struktur modal dan penilaian berasumsi bahwa ada modal optimal dan bahwa manajemen dapat menaikkan nilai total perusahaan melalui kebijakan penggunaan leverage finansial. Teori struktur modal tradisional terdiri dari:

a. Pendekatan laba bersih (Net Income Approach) yaitu pendekatan ini mengasumsikan bahwa investor mengkapitalisasi atau menilai laba perusahaan dengan tingkat kapitalisasi $\left(\mathrm{K}_{\mathrm{e}}\right)$ yang konstan dan perusahaan dapat meningkatkan jumah utangnya dengan biaya utang $\left(\mathrm{K}_{\mathrm{d}}\right)$ yang konstan pula. Karena $\mathrm{K}_{\mathrm{e}}$ dan $\mathrm{K}_{\mathrm{d}}$ konstan maka semakin busar jumlah utang yang digunakan perusahaan, biaya modal rata-rata tertimbang $\left(\mathrm{K}_{\mathrm{o}}\right)$ semakin kecil sebagai akibat penggunaan utang yang semakin besar, nilai perusahaan akan meningkat.

b. Pendekatan laba operasi bersih (net Income Approach $=\mathrm{NOI}$ Approach) yaitu pendekatan ini melihat bahwa biaya modal ratarata tertimbang konstan berapapun tingkat utang yang digunakan oleh perusahaan.

c. Pendekatan tradisional (Traditional Approach) merupakan pendekatan yang mengasumsikan bahwa hingga suatu leverage tertentu, risiko 
perusahaan tidak mengalami perubahan. Sehingga, baik $K_{d}$ maupun $\mathrm{K}_{\mathrm{e}}$ relative konstan. Namun demikian setelah leverage atau rasio utang (struktur modal) tertentu, biaya utang dan biaya modal sendiri meningkat. Pendekatan ini menyarankan bahwa perusahaan dapat membuat biaya modal lebih rendah dan menaikkan nilai total melalui menaikkan nilai leverage karena pendekatan tradisional struktur modal menyatakan bahwa biaya modal adalah dependen pada struktur modal perusahaan, dan adanya struktur modal optimum.

\subsection{Komponen struktur Modal}

Menurut Warsono $(2003: 236)$
struktur modal suatu perusahaan
secara umum terdiri dari dua
komponen, yakni hutang jangka
panjang dan modal sendiri, yang
diraikan sebagai berikut:

\subsubsection{Modal sendiri (equity capital)}

Modal sendiri adalah modal permanen, karena diinvestasikan dalam waktu yang lamanya tidak tentu, sepanjang perusahaannya masih beroperasi. Modal sendiri dalam suatu bisnis berbentuk :

a) Saham (stock)

Saham adalah surat berharga berupa tanda bukti penyertaan modal salam perusahaan.

b) Cadangan penyusutan (depreciation allowance)

Cadangan penyusutan merupakan dana penyusutan yang harus dicadangkan dari nilai mesin dan peralatan yang dimiliki perusahaan.

c) Laba yang ditahan (retained earning)

FASB Statement mendefinisikan laba akuntansi sebagai perubahan dalam net asset dari suatu entitas selama suatu periode tertentu yang diakibatkan oleh transaksi dan kejadian atau peristiwa yang berasal bukan dari pemilik. Secara umum, laba adalah keuntungan yang diperoleh perusahaan atas usahanya. Laba yang di-bagikan kepada para pe-megang saham disebut dividen, sedangkan laba di-tahan merupakan bagian dari keuntungan 
perusahaan yang tidak dibagikan sebagai deviden tetapi untuk ditanam kembali (reinvesment) dalam perusahaan.

\subsubsection{Hutang Jangka Panjang (long} term debt)

Menurut Sundjaja, Ridwan dan Bastian, Inge (2001 : 185) hutang jangka panjang merupakan salah satu bentuk yang penting dari pembiayaan jangka panjang. Pembiayaan jangka panjang diperoleh dalam bentuk pinjaman berjangka (term loan) melalui:

a. Negoisasi dengan kembaga keuangan atau;

b. Penjualan obligasi, seperti: penjualan sejumlah hutang kepada lembaga dan orangorang yang memberi pinjaman.

Pembiayaan jangka panjang adalah sumber pembiayaan yang jatuh temponya lebih dari 1 tahun biasanya antara 5 tahun s/d 20 tahun. Jika hutang jangka panjang jatuh tempo, akuntan akan menunjukkan saldo hutang jangka panjang sebagai hutang lancar sebab pada saat itu hutang tersebut merupakan kewajiban jangka pendek. Perlakuan yang sama diilakukan pada bagian hutang jangka panjang yang harus dibayar ditahun yang akan datang. Biaya hutang jangka panjang umumnya lebih besar dari biaya hutang jangka pendek. Faktor yang mempengaruhi biaya atau tingkat bunga yaitu:

a. Waktu jatuh tempo;

b. Besarnya pinjaman;

Besarnya pinjaman mempengaruhi biaya bunga pinjaman dengan cara berlawanan. Dengan jumlah pinjaman yang lebih besar maka biaya biaya administrasi pinjaman per-rupiah menjadi semakin kecil, tetapi risiko dari yang memberi pinjaman meningkat.

c. Resiko peminjam (borrower risk);

Lebih tinggi leverage operasi perusahaan, makin tinggi pula risiko bisnisnya. Makin tinggi debt ratio atau debt-equity ratio penerima pinjaman maka makin tinggi pula risiko keuangannya.

d. Biaya uang dasar (basic cost of money);

Biaya uang merupakan dasar 
untuk menentukan tingkat bunga.

Modal menunjukkan dana jangka panjang pada suatu perusahaan yang meliputi semua bagian dari sisi kanan neraca perusahaan. Modal pinjaman termasuk semua pinjaman jangka panjang yang diperoleh perusahaan.

Pemberi dana umumnya meminta pengembalian yang relative lebih rendah, karena mereka memperoleh risiko yang paling kecil atas segala jenis modal jangka panjang, sebab

1. Modal pinjaman mempunyai prioritas lebih dahulu bila terjadi tuntutan atas pen-dapatan/ aktiva yang tersedia untyuk pembayaran.

2. Modal pinjaman mempunyai kekuatan hukum atas pembayaran dibandingkan dengan pemegang saham (saham preferen atau saham biasa).

3. Bunga pinjaman merupakan biaya yang dapat mengurangi pajak, maka biasa modal pinjaman yang sebenarnya secara substansial menjadi lebih rendah.
Hubungan antara pinjaman dan modal sendiri mempunyai perbedaan utama dalam hak suara, tuntutan atas pendapatan dan aktiva, jatuh tempo, dan perlakuan pajak. Sesuai dengan posisinya, pemberi modal sendiri mempunyai risiko yang lebih besar dan karenanya harus mendapat kompensasi dengan pendapatan yang lebih tinggi dibandingkan pemberi dana pinjaman. (Julita, 2013 :9).

\subsection{Kebijakan Hutang}

Kebijakan utang termasuk kebijakan pendanaan perusahaan yang bersumber dari eksternal. Penentuan kebijakan utang ini berkaitan dengan struktur modal karena utang merupakan bagian dari penentuan struktur modal yang optimal. Perusahaan dinilai berisiko apabila memiliki porsi utang yang besar dalam struktur modal, namun sebaliknya apabila perusahaan mengunakan utang yang kecil atau tidak sama sekali maka perusahaan dinilai tidak dapat memanfaatkan tambahan modal eksternal yang dapat meningkatkan operasional perusahaan (Mamduh, 2004: 40). Menurut Mamduh (2004: 320) terdapat beberapa faktor yang 
memiliki pengaruh terhadap

kebijakan utang, antara lain :

a. NDT (Non-Debt Tax Shield) Manfaat dari penggunaan utang adalah bunga utang yang dapat digunakan untuk mengurangi pajak perusahaan. Namun untuk mengurangi pajak, perusahaan dapat menggunakan cara lain seperti depresiasi dan dana pensiun. Dengan demikian, perusahaan dengan NDT tinggi tidak perlu menggunakan utang yang tinggi.

b. Struktur Aktiva Besarnya aktiva tetap suatu perusahaan dapat menentukan besarnya penggunaan utang. Perusahaan yang memiliki aktiva tetap dalam jumlah besar dapat menggunakan utang dalam jumlah besar karena aktiva tersebut dapat digunakan sebagai jaminan pinjaman.

c. Profitabilitas Perusahaan dengan tingkat pengembalian yang tinggi atas investasinya akan menggunakan utang yang relatif kecil. Laba ditahannya yang tinggi sudah memadai membiayai sebagian besar kebutuhan pendanaan. d. d. Risiko Bisnis Perusahaan yang memiliki risiko bisnis yang tinggi akan menggunakan utang yang lebih kecil untuk menghindari risiko kebangkrutan.

e. Ukuran Perusahaan Perusahaan yang besar cenderung terdiversifikasi sehingga menurunkan risiko kebangkrutan. Di samping itu, perusahaan yang besar lebih mudah dalam mendapatkan pendanaan eksternal. Kondisi Internal Perusahaan Kondisi internal perusahaan menentukan kebijakan penggunaan utang dalam suatu perusahaan.

Utang dapat digolongkan ke dalam tiga jenis, yaitu (Riyanto, 2001) : (1) Utang jangka pendek (short-term debt), yaitu utang yang jangka waktunya kurang dari satu tahun. Sebagian besar utang jangka pendek terdiri dari kredit perdagangan, yaitu kredit yang diperlukan untuk dapat menyelengggarakan usahanya, meliputi kredit rekening koran, kredit dari penjual (levancier crediet), kredit dari pembeli (afnemers crediet), dan kredit wesel. (2) Utang jangka menengah (intermediate-term debt), yaitu utang yang jangka waktunya 
lebih dari satu tahun dan kurang dari sepuluh tahun. Kebutuhan membelanjai usaha melalui kredit ini karena adanya kebutuhan yang tidak dapat dipenuhi melalui kredit jangka pendek maupun kredit jangka panjang. Bentuk utama dari utang jangka menengah adalah term loan dan lease financing. (3) Utang jangka panjang (long-term debt) yaitu utang yang jangka waktunya lebih dari sepuluh tahun. Utang jangka panjang ini digunakan untuk membiayai ekspansi perusahaan. Bentuk utama dari utang jangka panjang adalah pinjaman obligasi (bonds-payable) dan pinjaman hipotik (mortage).

\subsection{Agresivitas Pajak}

Agressivitas pajak sebagai kegiatan perencanaan pajak semua perusahaan yang terlibat dalam usaha mengurangi tingkat pajak yang efektif. Perusahaan yang agresif terhadap pajak ditandai dengan transparansi yang lebih rendah. (Lanis dan Richardson, 2012)

tujuan utama dari aktivitas perencanaan pajak adalah menghindari pembayaran pajak atau membuat rendah beban pajak yang dibayarkan secara signifikan. Beban pajak yang dipikul oleh subjek pajak badan, memerlukan perencanaan yang baik, oleh karena itu strategi perpajakan menjadi mutlak diperlukan untuk mencapai perusahaan yang optimal. Strategi dan perencanaan pajak yang baik dan tentu saja harus legal, akan mampu mendorong perusahaan untuk dapat bersaing dengan perusahaan yang lain.

Ada berbagai macam proksi pengukuran agresivitas pajak, antara lain Effective Tax Rates (ETR), Book Tax Differences, Discretionary Permanent BTDs (DTAX), Unrecognize Tax benefit, Tax Shelter Activity, dan Marginal tax rate. Rego dan Wilson (2008) menyatakan bahwa tidak ada proksi agresivitas pajak yang dapat menangkap secara sempurna adanya agresivitas pajak. Beberapa peneliti menggunakan ETR untuk mengukur agresivitas pajak. Lanis dan Richardson (2012) menyatakan bahwa terdapat beberapa alasan menggunakan ETR sebagai proksi untuk mengukur agresivitas pajak adalah ETR untuk mengukur agresivitas pajak, proksi ETR adalah proksi yang paling banyak digunakan 
dalam literatur, dan nilai yang rendah dari ETR dapat menjadi indikator adanya agresivitas pajak. Secara keseluruhan, perusahaan-perusahaan yang menghindari pajak perusahan dengan mengurangi penghasilan kena pajak mereka dengan tetap menjaga laba akuntansi keuangan memiliki nilai ETR yang lebih rendah. Dengan demikin, ETR dapat digunakan untuk mengukur agresivitas pajak. Selain itu, dalam penelitian ini juga menggunakan proksi Book Tax Defference (BTD) sebagai proksi pengukuran alternatif agresivitas pajak untuk memperkuat hasil empiris penelitian ini. Book tax difference menggambarkan selisih antara laba akuntansi dengan laba fiskal. Perbedaan yang besar antara laba akuntansi dengan penghasilan kena pajak di perusahaan umumnya menunjukkan perilaku agresif terhadap pajak yang lebih besar. (Lanis dan Richardson, 2011).

\section{Metode Penelitian}

Objek dari penelitian ini adalah adalah aggresivitas pajak dan kebijakan hutang subjek dari penelitian ini adalah perusahaan manufaktur yang terdaftar di Bursa
Efek Indonesia tahun 2012-2014. Penelitian ini merupakan penelitian kuantitatif asosiaif yaitu penelitian yang tujuannya adalah untuk melihat pengaruh.dengan menggunakan alat analisis yaitu uji regresi berganda yang sebelumnya harus sudah memenuhi uji asumsi klasik.

\section{Hasil Penelitian dan Pembahasan}

\subsection{Penyajian Data}

Proxy yang digunakan dalam menguji variable dalam penelitian ini adalah Effektive Tax Ratio (ETR) dari perusahaan manufaktur yang terdaftar di Bursa Efek Indonesia tahun 20122014 untuk mewakili variable aggresivitas pajak. Cost of Debt untuk mewakili variable beban hutang.

\subsection{Analisis dan Interpretasi Uji Asumsi Klasik}

Data yang akan diuji regresi sebelumnya sudah melalui uji asumsi klasik. Berdasarkan data yang ada bahwa data telah terdistribusi normal terlihat dari grafik dimana titik-titik menyebar disekitar garis dan mengikuti garis diagonal seperti yang tertera pada gambar 4.1 


\section{Gambar 4.1}

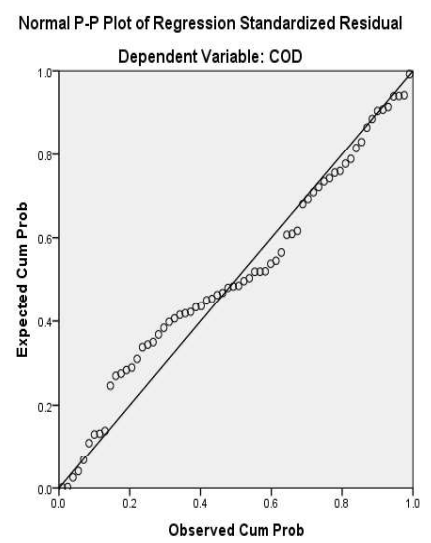

Uji multikolinieritas data yang digunakan dalam penelitian ini bebas dari multikolinieritas karena nilai VIF kurang dari 10 dan tolerance lebih dari 0,1 seperti terlihat pada table 4.1

Untuk uji autokorelasi guna mengetahui apakah model regresi ada korelasi antara residual pada periode $\mathrm{t}$ dengan residual pada periode sebelumnya.

Berdasarkan hasil uji bahwa nilai DW sebesar 1,7 berada pada daerah antara $\mathrm{du}<\mathrm{dw}<4$-du maka Ho diterima jadi dapat disimpulkan bahwa tidak terjadi autokorelasi.

Sedangkan untuk uji heterokedastisitas berdasarkan scaterplot bahwa titik-titiknya menyebar jadi dapat disimpulkan bahwa tidak tejadi masalah heterokedastisitas.

\subsection{Pengaruh Aggresivitas Pajak terhadap Beban Hutang}

Untuk menguji apakah terdapat pengaruh antara aggresivitas pajak terhadap beban hutang dilakukan uji regresi. Berdasarkan hasil olah data seperti yang terlihat pada table 4.1 diperoleh hasil bahwa hipotesis alternative ditolak yang artinya hipotesis nul diterima dimana nilai $\mathrm{T}$ hitung $=0,836$ sedangkan $\mathrm{T}$ table 1,999 sehingga Ha ditolak yang berarti bahwa tidak terdapat pengaruh aggresivitas pajak terhadap beban hutang. 
Tabel 4.1

\begin{tabular}{|c|c|c|c|c|c|c|c|}
\hline \multicolumn{8}{|c|}{ Coefficients $^{\mathrm{a}}$} \\
\hline \multirow[b]{2}{*}{ Model } & \multicolumn{2}{|c|}{$\begin{array}{l}\text { Unstandardized } \\
\text { Coefficients }\end{array}$} & \multirow{2}{*}{$\begin{array}{c}\text { Standardized } \\
\text { Coefficients } \\
\text { Beta }\end{array}$} & \multirow[b]{2}{*}{$\mathrm{t}$} & \multirow[b]{2}{*}{ Sig. } & \multicolumn{2}{|c|}{$\begin{array}{l}\text { Collinearity } \\
\text { Statistics }\end{array}$} \\
\hline & B & $\begin{array}{l}\text { Std. } \\
\text { Error }\end{array}$ & & & & Tolerance & VIF \\
\hline (Constant) & -.197 & .184 & & $\begin{array}{r}- \\
1.067\end{array}$ & .290 & & \\
\hline$\overline{\text { ETR }}$ & .000 & .000 & .107 & .836 & .406 & .945 & 1.058 \\
\hline
\end{tabular}

a. Dependent Variable: COD

\section{Simpulan}

Berdasarkan hasil olah data bahwa tidak terdapat pengaruh aggresivitas pajak terhadap beban hutang pada perusahaan manufaktur tahun 20122014. Penyebab besarnya beban pajak adalah bukan karena adanya kegiatan aggresivitas pajak yang artinya bahwa kegiatan perencanaan pajak yang dilakukan perusahaan yang dikenal dengan agresivitas pajak tidaklah dapat dijadikan factor yang mempengaruhi beban hutang sebagai pengindikator pemilihan sumber pendanaan melalui hutang.

\section{Daftar Pustaka}

Bambang Riyanto (2001), Manajemen Keuangan, Edisi 4, BPFE, Yogyakarta

Lanis, Richardson (2011), Corporate social responsibility and tax aggressiveness : a test of legitimacy theory, Journal of Applied Accounting Research

Mamduh Hanafi dan Abdul Halim (2004), Analisis Laporan Keuangan, Edisi ke 2, YKPN, Yogyakarta

Priyatno (2011), SPSS Analisis Statistik Data, Edisi 1,Media Kom, Yogyakarta

Rego and Wilson (2012), Equity Risk Incentives and Corporate Tax Aggressiveness, Journal of Accounting Research

Warsono (2003), Manajemen Keuangan Perusahaan, Edisi 3, Banyumedia Publishing, Malang 